\title{
Google Forms as Worksheets to Foster Students' Learning Interest and Autonomy During Online Mathematics Learning
}

\author{
Roni Priyanda, Nishbah Fadhelina, Iden Rainal Ihsan* \\ Department of Mathematics Education, Faculty of Teacher Training and Educational Sciences \\ Universitas Samudra \\ Kota Langsa, Indonesia \\ *irainalihsan@unsam.ac.id
}

\begin{abstract}
The Covid-19 pandemic demand change in education. Various online learning activities are arranged and presented so that learning continues to run effectively. In general, the aim of this research is to analyze the student worksheet assisted by Google forms (GF) during online mathematics learning. There are three specific aims in this study, i.e., the effectiveness of GF, the changes in student learning completeness, and the existence of students' learning interest and autonomy. As respondents, there are 102 students and 12 teachers in SMPN 5 Langsa. We conclude that the use of GF is very effective according to teachers' responses. We also get the result that more than a half of students could complete the learning. Finally, GF can be used to foster students' learning interest and autonomy.
\end{abstract}

Keywords—google form, worksheets, online learning, learning interest, learning autonomy

\section{INTRODUCTION}

The Covid-19 pandemic that is being felt globally recently requires almost all aspects of life to change. Education also changes in the implementation of learning, whether it is intended or not. The good change is that digital platforms can be used in learning. Thus, flexibility in learning can be felt by both educators and students. According to Hwang et al. [1], the online learning environment provides students with opportunities to exchange opinions with others and facilitate their self-regulated learning. Thus, with good online learning, students can have good learning autonomy. But, on the other hand, limitations become a barrier and even make distance learning a change that is not expected by various parties. For those with access to the internet and good resources, the challenges are big enough, even when highly educated parents are willing to help at home [2]. We refer to the opinion of Mailizar et al [3] who states that Indonesian secondary mathematics teachers faced a great challenge in using elearning as a tool of instruction during school closures as a result of the COVID-19 pandemic. The most significant barriers were at the student level including student lack of knowledge and skill in e-learning use, and their lack of access to devices and internet connection. So teachers have to conduct an instructional design to engage students which is not disturbed by the obstacle of online learning. Various obstacles should have solved by an intense interaction is required between the teacher and students in teaching and learning activities in mathematical subject [4].

With limited internet access, online learning will be difficult to implement properly. This appear because of the lack of interaction between teachers and students. According to Putra et al. [5], limited interaction between the teacher and students became another obstacle in understanding the mathematics contents. There is a need for assistance facilities that can overcome this gap in online learning activities. It is hoped that with the interaction, students' interest in learning can be well formed.

The need for all educational institutions, educators, and learners to adopt technology, and improve their digital skills in line with the emerge global trends and realities in education [6]. Teachers have to adopt new technology carefully because several scholars worried that quick adoption of new technology will lead to falling back to less favorable pedagogy [2]. Therefore, teachers and students in Indonesia in particular must be able to use information systems and technology [7], so that learning can be carried out more effectively. Effective is meant is the occurrence of a change or a desired result in an action [8].

In online learning, teachers should pay attention to the needs of students in the form of adequate online learning facilities, while maintaining interaction with students, preparing teaching materials that are easily understood, and providing motivation [4]. We are able to use an online worksheet for teaching (indirectly) a mathematical concept. Nowadays, we can choose many platforms that could be used as media in online learning. According to Onyema et al. [6], there are many technology tools/platforms to optimize online learning. There is one of online media that we could use as worksheet, namely google form (GF). It is part of Google which has many benefits, such as surveying activities, giving 
students quizzes and exercising with various forms of display or themes. GF could facilitate teacher activities in learning, e.g., a survey on teacher quality, questionnaire, registration, and form. Moreover, GF is environmentally friendly, it does not need a lot of paper and is free $[9,10]$. Student worksheets are learning media that contain a summary of questions, sample questions, and independent exercises that are arranged systematically and structurally so that students can learn the subject independently [11]. We can make a students' worksheet with using GF so that they will be more independent in learning. Thus, we are able to foster their learning autonomy, particularly in mathematics learning.

There is a question, how we could make GF as a good worksheet which has potential to foster students' learning interest and autonomy? We predict that learning mathematics that can generate interest is learning that is centered on solving problems in everyday life. Students can be stimulated to be involved in learning, because they know that there will be benefits in learning activities. Furthermore, students have reference which provide particular knowledge for them $[12,13]$.

How about student's learning autonomy? We cite Amelia et al. [4] who have surveyed that online learning could make students learn independently. However there a fact that online learning is inefficient. It because the cost of online learning is more expensive than direct learning (offline mode) [14]. GF is one of online platform that have good features and relatively affordable cost. We strongly agree that GF could be used as worksheet for fostering students' interest and autonomy in online mathematics learning.

Some of the advantages of GF as are that they have various kinds of tests such as descriptions, short essays or multiple choice. The appearance of an interesting, varied and interactive google form will also motivate students to learn and make it easier for teachers to assess because the results can be assessed directly [15]. Literature studies also provide the many benefits and advantages possessed by GF as a medium for distance learning including: the use of student worksheets assisted by GF is able to increase student learning independence, stimulate student interest in learning, and engage teacher interest [15]. The use of Google Forms has shown many benefits for students and lecturers interactively in the delivery and management of assignments. In addition, using questionnaire in GF is considered easier, more practical, and paperless. Moreover, it provides an impact and benefits from both the aspects of effectiveness, efficiency, attractiveness and display design. The result of research has been providing an information that using GF as worksheet is doable [16,17].

From the problem description and arguments about the potential of GF as a solution, our aim in this study is:

- Analyze the effectiveness of GF as worksheet in online mathematics learning;

- Analyze the changes in student learning completeness; and
- Analyze the existence of student's learning interest and autonomy after experiencing learning using GF as worksheets.

\section{METHODS}

Subjects of this study are 12 teachers and 102 students (36\% are 7 th grade students, $48 \%$ are 8 th grade, and $16 \%$ are 9th grade) at SMP Negeri 5 Langsa and the object of the research was the effectiveness of the GF assisted student worksheet. The instrument that used in this study are instruments and observation sheets. In this study We go through several processes and activities. The following figure 1 is the procedure flow in our study.

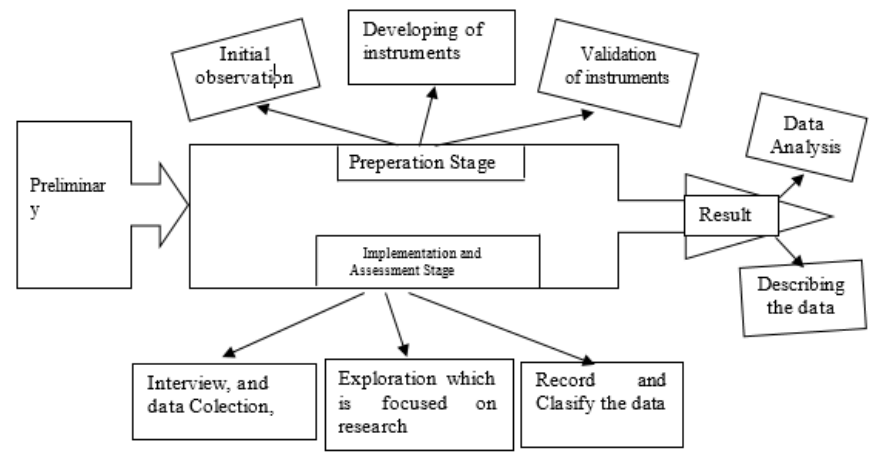

Fig. 1. Research Procedure.

\section{A. Preliminary}

First of all we observe condition in SMP Negeri 5 Langsa. We coordinate with the principal at SMP Negeri 5 Langsa, by conducting initial consultations, discussing problems faced by schools, especially the effectiveness of online learning.

\section{B. Validation Stage}

We develop an istructional design featured $\mathrm{GF}$ as worksheet. Then, we adapt the design to the curriculum in school. Next, the design is validated by senior lecturer. Finally, we revise the design based on feedback from validator.

\section{Implementation and Assessment}

In this stage, we observe learning activities using GF and collect data using quistionaire.

\section{Data Analysis}

In effort to get the appropiate result in this study, we analyze the data. In getting result of the first aim, we compute the average of teachers' responses. For the second aim we use formula and criteria shown in table 1 to analyze students' completeness in online mathematics learning. 
TABLE I. QUALITY OF STUDENTS’ COMPLETENESS

\begin{tabular}{|l|l|l|l|}
\hline \multicolumn{1}{|c|}{ Formula } & \multicolumn{1}{c|}{ Value } & \multicolumn{2}{c|}{ Criteria } \\
\hline $\mathrm{M}+1,5 . \mathrm{SD}$ & 70,93 & $\geq 71$ & Excellent \\
\hline $\mathrm{M}+0,5 . \mathrm{SD}$ & 65,53 & $66-70$ & Good \\
\hline $\mathrm{M}-0,5 . \mathrm{SD}$ & 60,13 & $61-65$ & Moderate \\
\hline $\mathrm{M}-1,5 . \mathrm{SD}$ & 54,73 & $55-160$ & Fair \\
\hline & & $\leq 54$ & Poor \\
\hline
\end{tabular}

The result of completeness is used also for analyzed students' learning autonomy. Students' responses is analyzed also to get information related to their interest in online mathematics learning.

\section{RESULTS AND DISCUSSIONS}

\section{A. Result}

We provide figure 2 and figure 3 as examples of our GF worksheet tht used in implementation stages. We have three main result in this study, i.e., the effectiveness, the completeness, and the existence of students' learning interest and autonomy. We analyze the effectiveness of GF as worksheet through teachers' responses based on indicator [9].The effectiveness of the use of GF obtained by tabel 2.

\section{TABLE II. TEACHERS RESPONSES}

\begin{tabular}{|c|c|c|}
\hline No & Indicator & Percentage \\
\hline 1 & $\begin{array}{l}\text { The use of Google Form as Worksheet during } \\
\text { online mathematics learning can make time } \\
\text { more efficient }\end{array}$ & 90.91 \\
\hline 2 & $\begin{array}{l}\text { The use of Google Forms as Worksheet during } \\
\text { online mathematics learning can make energy } \\
\text { efficient }\end{array}$ & 90.91 \\
\hline 3 & $\begin{array}{l}\text { The use of Google form as Worksheet during } \\
\text { online mathematics learning can make costs } \\
\text { efficiency }\end{array}$ & 96.36 \\
\hline 4 & $\begin{array}{l}\text { Practicality of using Google forms as Worksheet } \\
\text { during online mathematics learning }\end{array}$ & 94.55 \\
\hline 5 & $\begin{array}{l}\text { Clarity in the use of Google forms as Worksheet } \\
\text { during online mathematics learning }\end{array}$ & 89.09 \\
\hline 6 & $\begin{array}{l}\text { Use of Google form as Worksheet during online } \\
\text { mathematics learning is easy to Understand }\end{array}$ & 89.09 \\
\hline 7 & $\begin{array}{l}\text { Use of Google form as Worksheet during online } \\
\text { mathematics learning is easy to access }\end{array}$ & 89.09 \\
\hline 8 & $\begin{array}{l}\text { Use of Google form as Worksheet during online } \\
\text { mathematics learning is useful }\end{array}$ & 92.73 \\
\hline 9 & $\begin{array}{l}\text { Enjoyment Use of Google form as Worksheet } \\
\text { during online make me enjoyed Using it }\end{array}$ & 90.91 \\
\hline 10 & $\begin{array}{l}\text { Google Forms as Worksheet during online } \\
\text { mathematics learning has an interesting } \\
\text { Appearance }\end{array}$ & 94.55 \\
\hline 11 & $\begin{array}{l}\text { Using Google form as Worksheet during online } \\
\text { mathematics learning can Increase students' } \\
\text { learning interest and autonomy }\end{array}$ & 90.91 \\
\hline \multicolumn{2}{|c|}{ Average } & 91.74 \\
\hline \multicolumn{2}{|c|}{ Information } & Very Effective \\
\hline
\end{tabular}

Tabel 2 show that teacher provide a positive responses. We could conlcude that the use of GF is very effective.

According formula in table 1 , we get score 62,83 as the completeness of students. Then we are also use the information in table to know the criteria of completeness. Related to its information, we conclude that the criteria of completeness is moderate.

For students' learning interest, table 3 could provide the distribution.

TABLE III. FREQUENCY DISTRIBUTION OF STUDENT LEARNING INTEREST

\begin{tabular}{|l|l|l|l|}
\hline No. & \multicolumn{1}{|c|}{ Range } & \multicolumn{1}{|c|}{$\begin{array}{c}\text { Absolute } \\
\text { Frequency }\end{array}$} & $\begin{array}{c}\text { Relative } \\
\text { Frequency(\%) }\end{array}$ \\
\hline 1 & $46-50$ & 2 & 1,96 \\
\hline 2 & $51-55$ & 7 & 6,86 \\
\hline 3 & $56-60$ & 18 & 17,65 \\
\hline 4 & $61-65$ & 48 & 47,06 \\
\hline 5 & $66-70$ & 21 & 20,59 \\
\hline 6 & $71-76$ & 4 & 3,92 \\
\hline 7 & $77-80$ & 2 & 1,96 \\
\hline Sum & 102 & 100 \\
\hline
\end{tabular}

More than a half of students have a good interest in online learning

\section{B. Discussions}

The autonomous learning skill set involves a variety of different factors, including knowledge, ability, attitude and motivation of the students [18]. in addition to the various constraints the learning environment imposes on learning, such as curriculum requirements, teaching and learning approaches, and institutional control [18] meta-theory of instructional design $[19,20]$. The theory explain that:

- Learning is promoted when learners are engaged in solving real-world problems (problem-centered principle).

- Learning is promoted when existing knowledge is activated as a foundation for new knowledge (activation principle).

- Learning is promoted when new knowledge is demonstrated to the learner (demonstration principle).

- Learning is promoted when new knowledge is applied by the learner (application principle).

- Learning is promoted when new knowledge is integrated into the learner's world (integration principle).

The use of GF in our study accomodate all of meta-theory of instructional design. So that why there exists students' learning interest and autonomy. See figure 2 and figure 3 below. 


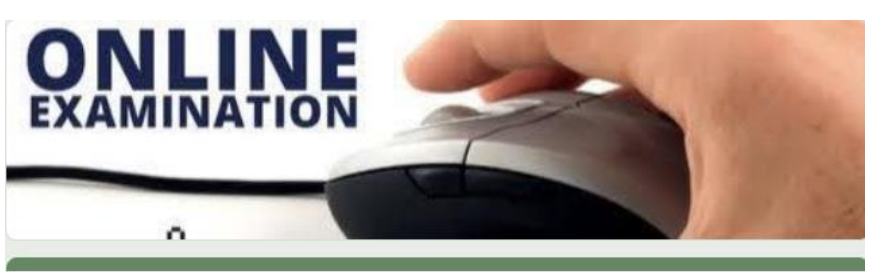

\section{Examination}

Are you ready?

The name and photo associated with your Google account will be recorded when you upload files and submit this form. Not roni@unsam.ac.id? Switch account

$$
\text { * Required }
$$

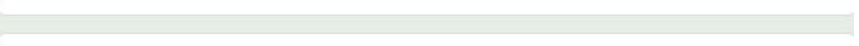

Name *

Your answer

Fig. 2. Cover and student profile.

Essai

1. Do the following questions in the book then upload them to the link that has been provided *

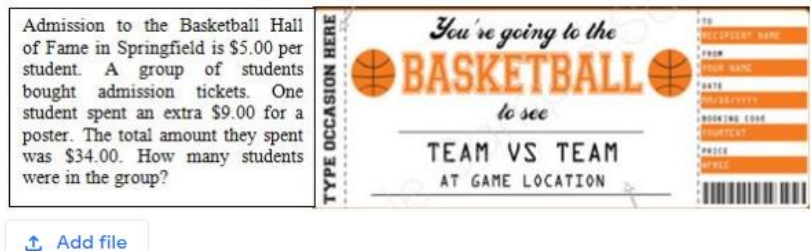

Back

\section{Submit}

Fig. 3. Form student's worksheet.

\section{CONCLUSIONS}

The following is conclusions of this study :

- Teachers' responses provide the information that the use of GF as worksheet is very effective. It is concluded because the average of response shows a high percentage, i.e. $91,74 \%$;

- The level of completeness of students in learning is classified as moderate in terms of the acquisition value of 62.83 ; and

- The use of GF as worksheet could foster students' learning interest and autonomy. Relative Frequency show that only few students that did not have high interest in learning. The conclusion related to learning autonomy is got by analyze the level of completeness. More than a half of students have completed their learning independently.

\section{ACKNOWLEDGMENT}

On this occasion, we would like to thank the Institute of Research and Community Services/ LPPM of Universitas Samudra for funding on this research. We also thanks to all mathematics teacher and students in SMP Negeri 5 Langsa, Aceh, Indonesia, for their pleasure to collaborate in this research.

\section{REFERENCES}

[1] G.J. Hwang, S.Y. Wang, and C.L. Lai, "Effects of a social regulationbased online learning approach on students' learning achievements and behaviors in mathematics," Computers \& Education, 2020.

[2] A. Bakker and D. Wagner, "Pandemic: lessons for today and tomorrow?" Educational Studies in Mathematics, vol. 104, pp. 1-4, 2020 .

[3] Mailizar, A. Almanthari, S. Maulina, and S. Bruce, "Secondary school mathematics teachers' views on e-learning implementation barriers during the covid-19 pandemic: the case of Indonesia." Eurasia Journal of Mathematics, Science and Technology Education, vol. 16, no. 7, p. 1860, 2020.

[4] R. Amelia, G. Kadarisma, N. Fitriani, and Y. Ahmadi, "The effect of online mathematics learning on junior high school mathematic resilience during covid-19 pandemic.” J. Phys.: Conf. Ser., vol. 1657, p. 012011, 2020.

[5] Z.H. Putra, G. Witri, and I.K. Sari, "Prospective elementary teachers' perspectives on online mathematics learning during coronavirus outbreak.” J. Phys.: Conf. Ser., vol. 1655, p. 012057, 2020.

[6] E.D. Onyema, N.C. Eucheria, F.A. Obafemi, S. Sen, F.G. Atonye, A. Sharma and A.O. Alsayed, "Impact of Coronavirus Pandemic on Education," Journal of Education and Practice, vol. 11, no. 13, pp. 108 121, 2020.

[7] S. Mustapha, M.S. Rosli, and N.S. Saleh, "Online learning environment to enhance HOTS in mathematics using Polya's problem solving model.” J. Phys.: Conf. Ser., vol. 1366, p. 012081, 2019.

[8] R. Priyanda, "Efektifitas Penggunaan Media Pembelajaran Matematika menggunakan media CAI dengan tipe tutorial terhadap hasil belajar siswa di SMK Muhammadiyah 9 Medan," Jurnal Dimensi Matematika, vol. 2, no. 1, 2019.

[9] F. Fadilah, R. Amalia, and R. Priyanda, "The Effectiveness of Using Lectora Based on Aceh Culture on Linear Equation System Material." BIRCI-Journal, vol. 3, no. 4, pp. 3084-3090, 2020.

[10] M. Iqbal, Rosramadhana, B.K. Amal, and M.E. Rumapea, "Penggunaan google form sebagai Media Pembelajaran tugas Mata Kuliah Pengantar.' Ilmu Sosial JUPIIS (Jurnal Pendidkan Ilmu Sosial), vol. 10, no. 1, pp.120-127, 2018.

[11] R.D. Fannie and Rohati, "Pengembangan Lembar Kerja Siswa (LKS) berbasis POE (Predict, Observe, Explain) pada materi program linier," Jurnal Sainmatika, vol. 8, no. 1, 2014.

[12] I.W. Suastra, N.K. Suarni, and K.S. Dharma, "The effect of Problem Based Learning (PBL) model on elementary school students' science higher order thinking skill and learning autonomy.” J. Phys.: Conf. Ser., vol. 1318, p. 012084, 2019.

[13] Ilmadi, R.H. Zarista, Aden and G. Sastra, "The effectiveness of online learning for mathematics students during the covid-19 pandemic (case study-mathematics study program. Pamulang university).” Jurnal Cendekia: Jurnal Pendidikan Matematika, vol. 4, no. 2, pp. 1273-1282, 2020.

[14] A.N. Bahasoan, W. Ayuandiani, M. Mukhram and A. Rahmat, "Effectiveness of Online Learning In Pandemic Covid-19." International Journal of Science, Technology \& Management, vol. 1, no. 2, pp. 100$106,2020$. 
[15] H. Hanafiah, R. Priyanda, and N. Fadhelina, "The effectiveness of using google form assisted student worksheets in increasing learning independance and student mathematic comunication skills in SMP Negeri 5 Langsa,” BIRCI-Journal, vol. 3, no. 4, pp. 3091-3092, 2020.

[16] I.B. Asfyra, Z. Zulkardi, R.I.I. Putri, and Y. Hartono, "Mathematics learning of trigonometric triangles in vocational high school using online media.” J. Phys.: Conf. Ser., vol. 1663, p. 012025, 2020.

[17] I.E. Allen and C.A. Seaman, "Likert Scales and data anayses. Qualitaty progres," 2007.

[18] L. Elliot, A. Gehret, M.S. Valadez, R. Carpenter, and L. Bryant, "Supporting autonomous learning skills in developmental mathematics courses with asynchronous online resources." American Behavioral Scientist, vol. 64, no. 7, pp. 1012-1030, 2020.

[19] M.D. Merrill, "First principles of instruction." Educational Technology Research and Development, vol. 50, no. 3, pp. 43-59, 2002.

[20] C.K. Lo and K.F. Hew, "A comparison of flipped learning with gamification, traditional learning, and online independent study: the effects on students' mathematics achievement and cognitive engagement." Interactive Learning Environments, vol. 28, no. 4, pp. 464-481, 2020. 